\title{
Can climate and soil conditions change the morpho-anatomy among individuals from different localities? A case study in Aldama grandiflora (Asteraceae)
}

\author{
L. F. Muniz ${ }^{*}$, A. B. Bombo ${ }^{a}$, A. L. Filartiga ${ }^{a}$ and B. Appezzato-da-Glória ${ }^{a}$ \\ ${ }^{a}$ Plant Anatomy Laboratory, Plant Physiology and Biochemistry, Biological Sciences Department, \\ College of Agriculture "Luiz de Queiroz" - ESALQ, University of São Paulo - USP, Av. Pádua Dias, nº 11, \\ CEP 13418-900, Piracicaba, SP, Brazil \\ *e-mail larissa.muniz@usp.br
}

Received: January 19, 2017 - Accepted: July 14, 2017 - Distributed: November 30, 2018

(With 3 figures)

\begin{abstract}
Vegetative aerial organs are considerably more exposed to environmental conditions and can reflect the specific adaptations of plants to their local environment. Aldama grandiflora species are known to be widely distributed in Brazil; therefore, individuals from different populations of this species are thought to be exposed to different abiotic and biotic conditions. Several anatomical studies conducted on Brazilian Aldama species have mainly focused on the qualitative anatomical characters or traits of these species, but not on their quantitative traits. In this study, we evaluated whether climate and soil conditions can change the morphometry among individuals of $A$. grandiflora collected from six sites in the Goiás State, Brazil, by assessing their anatomical characters. Further, soil sampling was performed, and climate data were collected from all the six sites. The analysis indicated few statistical differences among the populations evaluated, showing that $A$. grandiflora presented consistent leaf and stem anatomical characteristics. The small morpho-anatomical differences found among individuals of the different populations evaluated, reflected the soil conditions in which these populations were grown. Therefore, environmental factors have a significant influence on the morpho-anatomy of Aldama grandiflora.
\end{abstract}

Keywords: cerrado, Compositae, morphometry, phenotypic plasticity, leaf anatomy.

\section{Condições climáticas e de solo podem alterar a morfo-anatomia entre indivíduos de diferentes localidades? Um estudo de caso em Aldama grandiflora (Asteraceae)}

\begin{abstract}
Resumo
Os órgãos vegetativos aéreos estão consideravelmente mais expostos às condições ambientais e podem refletir as adaptações específicas das plantas ao seu habitat. A espécie Aldama grandiflora é amplamente distribuída no Brasil e, dessa forma, indivíduos de diferentes populações podem estar expostos a diferentes condições ambientais. Vários estudos anatômicos realizados com espécies brasileiras do gênero Aldama têm abordado, principalmente, as características anatômicas qualitativas dessas espécies, mas não em suas características quantitativas. Neste estudo avaliamos se as condições climáticas e do solo podem alterar a morfometria entre os indivíduos de $A$. grandiflora coletados em seis populações do Estado de Goiás. Foram avaliados os caracteres anatômicos foliares e caulinares, além da amostragem do solo e coleta de dados climáticos, para os seis locais. A análise indicou algumas diferenças estatísticas entre as populações avaliadas, mostrando que $A$. grandiflora apresentou características anatômicas foliares e caulinares bastante consistentes. As pequenas diferenças morfo-anatômicas encontradas entre indivíduos das diferentes populações avaliadas, refletiram as condições do solo nos quais essas populações se desenvolveram. Assim sendo, fatores ambientais relacionados ao clima e condições do solo têm uma influência significativa sobre a morfo-anatomia de Aldama grandiflora.
\end{abstract}

Palavras chave: cerrado, Compositae, morfometria, plasticidade fenotípica, anatomia foliar.

\section{Introduction}

The family Asteraceae accounts for approximately $10 \%$ of the world's flora (Panero and Crozier, 2012) and is one of the most important among angiosperms, comprising around 1620 genera and 23600 species (Stevens, 2001). Being a large family, the niches occupied by its species vary substantially and a considerable number of anatomical 
differences can be explained by phenotypic plasticity (Metcalfe and Chalk, 1983), which allow adaptation to different environmental conditions (Dickison, 2000).

The tribe Heliantheae, which occurs in the Cerrado, is the second largest tribe of the family, comprising 189 genera and around 2500 species. Among its representatives is Aldama La Llave, a South American genus, which includes 35 Brazilian species, of which 17 are endemic (Magenta et al., 2010). The representatives of this genus are morphologically very similar, leading to problems in taxonomical delimitations among the species (Schilling and Panero, 2011).

Aldama grandiflora (Gardner) E.E. Schill. \& Panero (=Viguiera grandiflora) is widely distributed in open areas from the Cerrado, the second largest plant formation in Brazil, and can be found in different geographic regions such as North (Amazonas state), Northeast (Bahia), Midwest (Distritio Federal, Goiás, Mato Grosso do Sul and Mato Grosso states), Southeast (Minas Gerais), and South (Paraná). This species stands out in Aldama genus because, in addition to its wide distribution, it has resiniferous potential (Magenta and Pirani, 2014) and high yield of essential oils (data not published), with several compounds having proven biological activity (Leite et al., 2007; Canales et al., 2008; Santos et al., 2011). This species is characterized by intraspecific structural variations and high degree of polymorphisms in color and shape of the leaf blade since its representatives are tolerant to different light intensities (Magenta and Pirani, 2014). Several taxonomic studies have been conducted on Brazilian Aldama species (Bombo et al., 2012, 2014; Oliveira et al., 2013; Silva et al., 2014); however, such studies have addressed only the qualitative anatomical characters of these species, but not the quantitative traits.

Environmental factors related to climate, such as water relations, photoperiod, and light intensity, as well as soil parameters such as chemical and physical characteristics, in addition to the relief and elevation of the area, significantly influence the morphology and anatomy of plants (Olsen et al., 2013). According to Scheiner (1993) and Stearns (1989), phenotypic plasticity relates to the capacity of an organism to change its physiology or morphology in response to environmental conditions. The species $A$. grandiflora, in which the organs related to survival show high phenotypic capacity (Magenta and Pirani, 2014), could have adaptive advantages when exposed to unfavorable environments (Gardoni et al., 2007) and these changes would increase the environmental stress tolerance of the plant, favoring its occupancy to new niches (Stearns, 1989; Scheiner, 1993).

Plant organs such as leaves are the most exposed to environmental factors, and structural changes owing to phenotypic plasticity can be interpreted as specific adaptations to the local environment (Fahn, 1986; Dickison, 2000). The characters of stems, mainly those related to the vascular system, which are parameters that determine the efficiency and water resistance capacity (Kuniyoshi, 1993), can also exhibit variations in response to changes in relative humidity, temperature, and salinity (Yaltirik,
1970; Baas, 1982; Carlquist, 1988); therefore, they are crucial in maintaining these individuals in their habitat.

Since $A$. grandiflora is a well-represented Brazilian species owing to its widespread occurrence and geographic distribution, its individuals are submitted to different abiotic and biotic conditions that may have influence in their morpho-anatomy according to the locality in which they develop. Hence, in this study, we evaluated whether the leaf and stem anatomical characters of $A$. grandiflora can vary within the same species according to the environment in which they are grown, considering populations grown in different localities and, consequently, different soil and climatic conditions. This study aimed to evaluate whether (a) the morphometric anatomical parameters of the leaves and stems of $A$. grandiflora from six different populations sampled from two regions varied among populations and (b) variation occurred among these populations, and was it a consequence of the edaphoclimatic conditions to which these populations were exposed. Answers to these questions might provide better insight into the relations between the morpho-anatomy of the vegetative aerial organs and abiotic factors for Aldama species.

\section{Material and Methods}

Plant material and collection areas: Leaves and stems of $A$. grandiflora were sampled from adult plants from six different sites, each site representing one different population; three of them were collected from Region 1 (Brasília, Distrito Federal, and Planaltina, Goiás State) and the remaining three were collected from Region 2 (Alto Paraíso de Goiás, Goiás State; Figure 1). From each site, 10 plants were sampled, totaling 60 individuals. The two regions are more than $200 \mathrm{~km}$ away. All the populations from Region 1 were collected from roadside areas, from the remnants of the original vegetation, i.e., Cerrado vegetation (Figure 2A-C); fire incidences had occurred in the three areas. The three sites in Region 2 (Figure 2D-F) slightly differed from each other: Site 4 was an urban area and samples were collected from roadsides; Site 5 was a firebreak area inside the National Park Chapada dos Veadeiros; and Site 6 was a Cerrado remnant range at a roadside near the National Park. Only few plants for the last population were found, and evidence of fire was found in this area.

Information about the collection areas and geographic coordinates are shown in Table 1. Vouchers were registered and incorporated into the collection at the Luiz de Queiroz School of Agriculture, University of Sao Paulo (ESA herbarium).

Anatomical analysis: All the samples were fixed in FAA 50 (formaldehyde, acetic acid, and 50\% ethanol, $1: 1: 18$; (Johansen, 1940)), placed in a vacuum pump to remove air from the tissue, dehydrated in a graded ethanol series, and stored in $70 \%$ ethanol. For each individual, one fully expanded leaf corresponding to the medium size for the species according to Magenta (2006) was selected and, from this leaf, samples of the internervural and midrib 


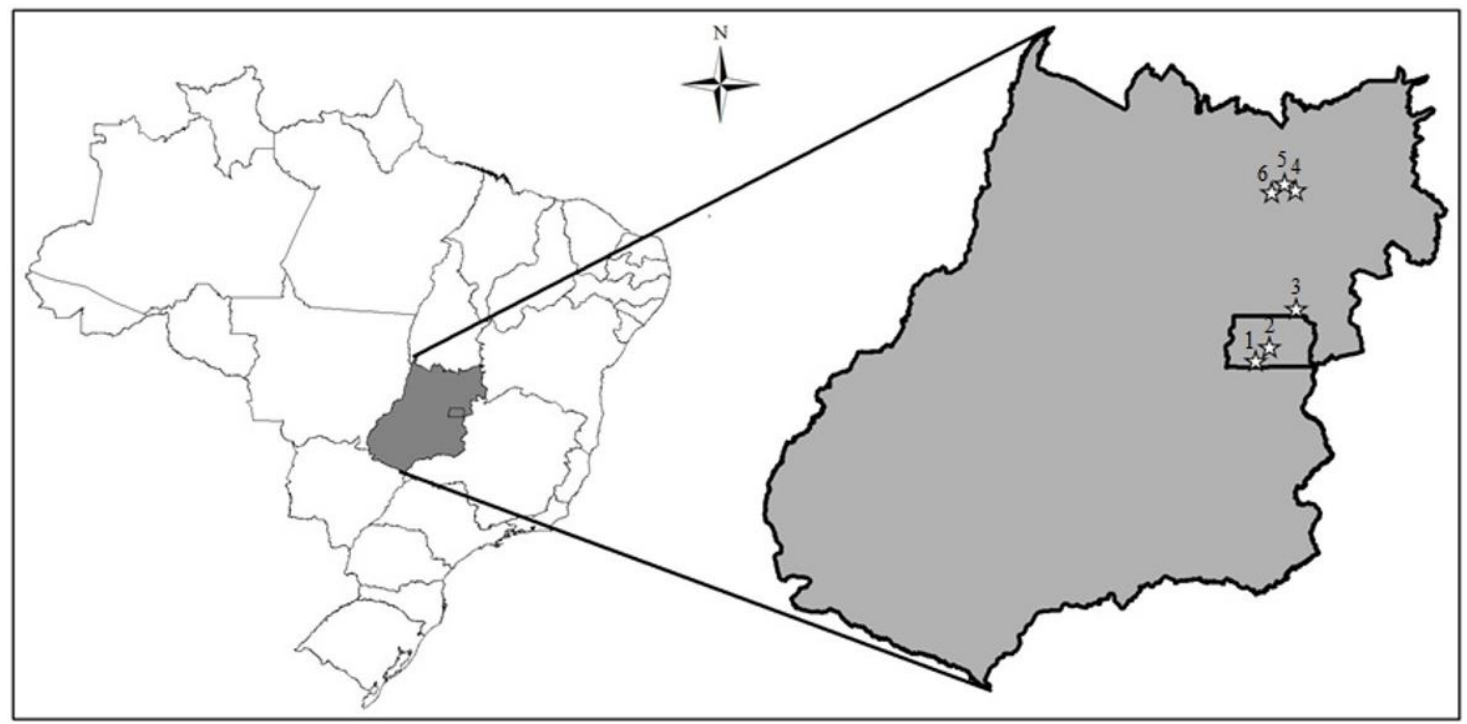

Figure 1. Localization of the sampled populations of Aldama grandiflora in Goiás State. $1=$ population $1 ; 2=$ population 2; $3=$ population $3 ; 4=$ population $4 ; 5=$ population $5 ; 6=$ population 6 .

Table 1. Location, Latitude (S), Longitude (W), and voucher number of the sampled population of Aldama grandiflora.

\begin{tabular}{|c|c|c|c|}
\hline Site & City, State & $\begin{array}{c}\text { Latitude (S) } \\
\text { Longitude (W) }\end{array}$ & Voucher \\
\hline 1 & Brasília/DF & 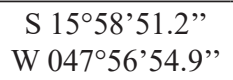 & ESA134833 \\
\hline 2 & Brasília/DF & $\begin{array}{c}\text { S 15॰50’05.6" } \\
\text { W } 047^{\circ} 48^{\prime} 13.1^{\prime \prime}\end{array}$ & ESA134834 \\
\hline 3 & Planaltina/GO & 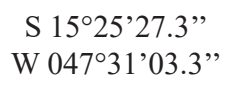 & ESA134835 \\
\hline 4 & $\begin{array}{l}\text { Alto Paraíso de } \\
\text { Goiás/GO }\end{array}$ & $\begin{array}{c}\text { S 1408'34.9"' } \\
\text { W 047³1'19.8" }\end{array}$ & ESA134836 \\
\hline 5 & $\begin{array}{l}\text { National Park } \\
\text { Chapada dos } \\
\text { Veadeiros- } \\
\text { Alto Paraíso } \\
\text { de Goiás/GO } \\
\text { (Mulungu) }\end{array}$ & $\begin{array}{c}\text { S 1404'24.0"' } \\
\text { W 047³8'09.7'" }\end{array}$ & ESA134837 \\
\hline 6 & $\begin{array}{l}\text { Alto Paraíso de } \\
\text { Goiás/GO (Vale } \\
\text { da Lua) }\end{array}$ & $\begin{array}{c}\text { S 1410'06.2"' } \\
\text { W 04746'29.8" }\end{array}$ & ESA134838 \\
\hline
\end{tabular}

regions were obtained. Aerial stems were sampled from three different individuals for each population, and the internode nearest to the soil level, and therefore, the oldest portion of aerial stem, for each individual was examined.

The fixed samples were dehydrated in a graded ethanol series and embedded in plastic resin (Leica Historesin ${ }^{\circledR}$ ) according to the manufacturer instructions. The blocks were sectioned (5-8 $\mu \mathrm{m}$ thick) using a Leica RM 2045 rotary microtome. Sections were stained with $0.05 \%$ toluidine blue $\mathrm{O}$ in a citrate-phosphate buffer, $\mathrm{pH} 4.5$ (Sakai, 1973) and mounted in Entellan ${ }^{\circledR}$ synthetic resin (Merck, Darmstadt, Germany). Sudan IV for lipophilic substance detection (Jensen, 1962) and ruthenium red for pectic and mucilaginous substances (Johansen, 1940) were also applied to the sections.

For stomata and epidermal cell counting, in order to calculate the stomatal index (SI), the epidermis dissociation technique involving the use of $10 \%$ Jeffrey solution was applied before observing the frontal view of the leaves (Johansen, 1940). Fragments were stained with safranin and astra blue (Bukatsch, 1972) and mounted in glycerinated gelatin. The SI was calculated according to the formula: $\mathrm{SI}=\mathrm{S} /(\mathrm{E}+\mathrm{S})$, where $\mathrm{S}$ is the number of stomata, and $\mathrm{E}$ is the number of epidermal cells (Cutter, 1986). The leaf area was determined using Area Meter Modelo Li-3000 equipment (Li-Cor Inc., USA).

For the leaves and stems, the following parameters were considered: cuticle thickness in the adaxial surface; height of epidermal cells and thickness of the outer periclinal external walls of both leaf sides; mesophyll thickness; number and distribution of secretory ducts in the ground parenchyma of the midrib; midrib height and width; internode diameter; number of cell layers and thickness of the cortex; number of ducts in the cortex; total stem area; and total area of the vascular cylinder. For each parameter, five measurements/counting were performed, and an average was obtained for each individual.

Photomicrographs were obtained using a Leica DMLB microscope and Leica DFC310Fx camera. LAS 4.0 software (Leica) was used for image analysis. For measurement and counting, Image J Software (Rasband, 2006) was used.

Soil sampling and analysis: Chemical and physical analyses of the soil samples were performed for each site. From each collection site (Table 1), ten soil samples (500 $\mathrm{g}$ each) from the depth of 0-20 cm were obtained using a sampler soil probe (S-60 SONDATERRA ${ }^{\circledR}$ model). These ten samples for each site were mixed to form a composite sample for each site. The analyses were performed to 

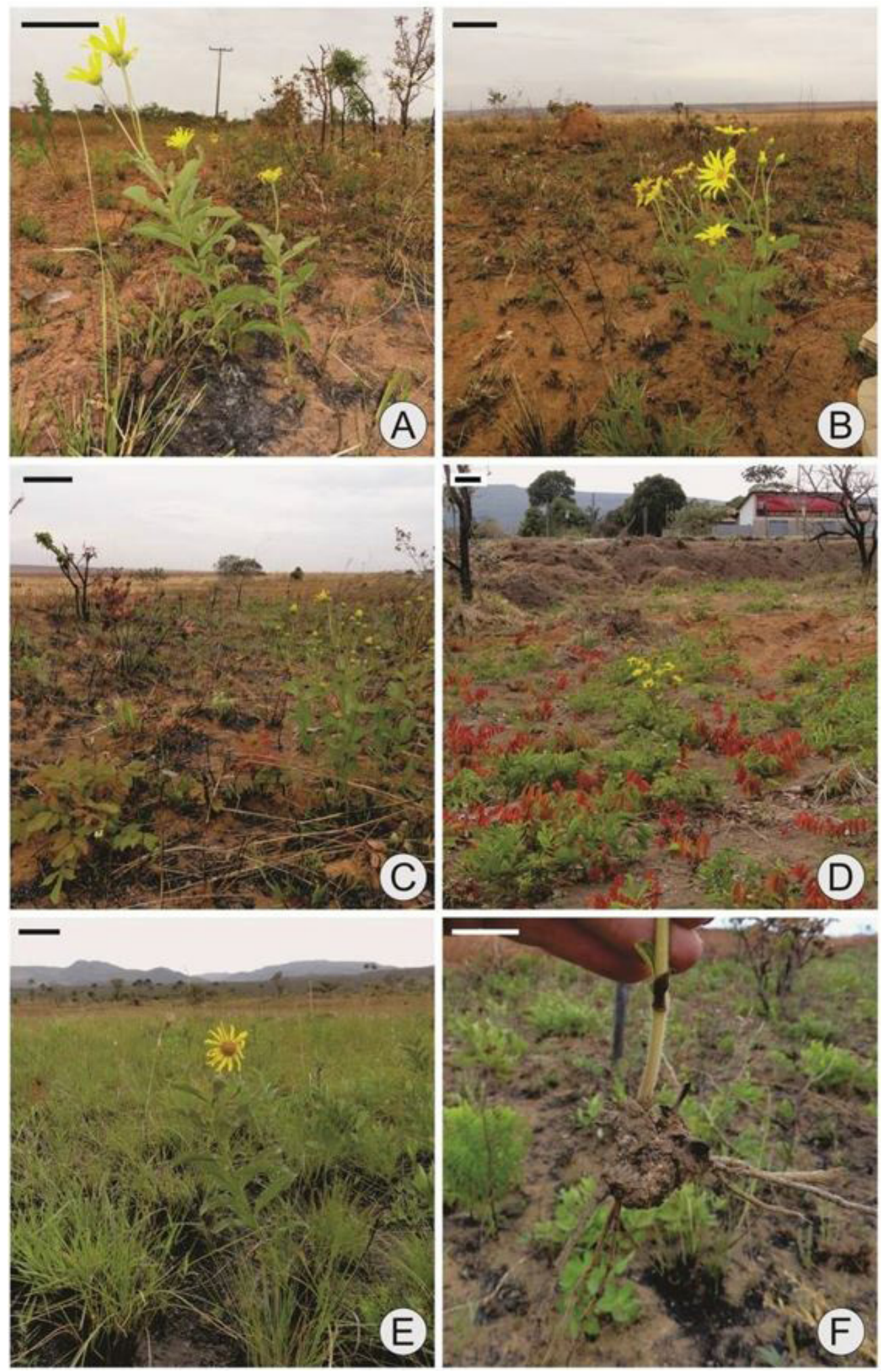

Figure 2. General view of the field in which the six Aldama grandiflora populations were grown. A. Site 1, Brasília/DF. B. Site 2, Brasília/DF. C. Site 3, Planaltina/GO. D. Site 4, Alto Paraíso de Goiás/GO. E. Site 5, National Park Chapada dos Veadeiros-Alto Paraíso de Goiás/GO (Mulungu). F. Site 6, Alto Paraíso de Goiás/GO (Vale da Lua). The carbonized bases of some aerial branches (arrows) and details of the underground system can be noted. Scale Bars: A-C, E = $10 \mathrm{~cm} ; \mathrm{D}=20 \mathrm{~cm}$; $\mathrm{F}=2 \mathrm{~cm}$. 
evaluate the granulometry of the soil, detect and identify micronutrients, and classify the soils.

Environmental data: For the six sites, the mean annual temperature, annual precipitation, and altitude data were collected. All the environmental parameters were obtained from Worldclim website (Hijmans et al., 2005), and the values represented interpolations of observed data, which were representative of data from 1950 to 2000 .

Statistical analysis: Mean and standard deviation values were obtained for each parameter for both leaf and stem organs for each population; the normality was confirmed using Kolmogorov-Smirnov \& Lilliefors and Shapiro-Wilk's tests (Kolmogorov, 1933; Shapiro and Wilk, 1965; Lilliefors, 1967). The values were then submitted to analysis of similarity (ANOVA) and Tukey's test to determine the existence of potential differences among the populations. When necessary, the data were log transformed. The correlations ( $r$ ) between morphometrical values and between morphometrical and edaphic-climatic variables were also analyzed. Statistical significance was set at $p<0.05$. All analyses were performed using STATISTICA 10 software (StatSoft, Tulsa, Oklahoma, USA).

\section{Results}

Leaf and stem morphometry: In Figure 3, images of the leaf (Figure 3A and 3B) and stem (Figure 3C and 3D) of Aldama grandiflora are arranged. Among the foliar parameters evaluated, the thickness of the cuticle in the adaxial surface of the leaf blade showed significant statistical
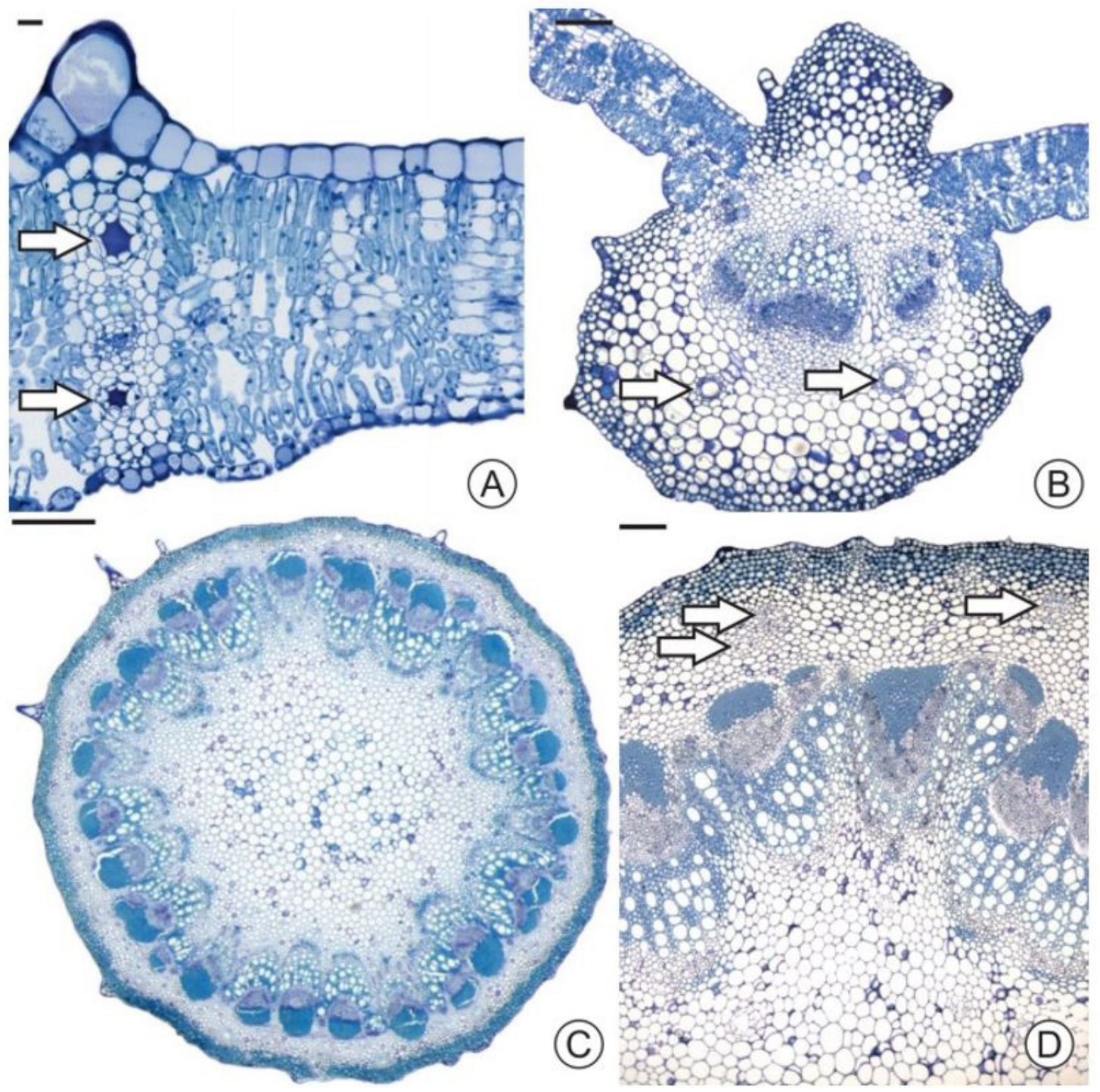

Figure 3. Photomicrographs of leaves (A-B) and stems (C-D) of Aldama grandiflora. A-B. Cross sections of leaf blade (A) and midrib (B). C-D. Cross sections of the aerial stem. C. Overview. D. Detail of the secretory ducts in the cortical parenchyma. Arrows indicate secretory ducts. Bars: A-B, $\mathrm{D}=100 \mu \mathrm{m}$ and $\mathrm{C}=500 \mu \mathrm{m}$. 
difference between the two regions and similarity between sites collected from the same region (Table 2). For the other parameters, the range was not restricted to the study sites, i.e., individuals from populations from the two regions had the same condition for a given parameter. In addition to cuticle thickness, the parameter that significantly differed between the populations was SI of both the leaf sides; the height of the midrib, which was positively correlated with the thickness of the outer periclinal external walls of the adaxial surface of the leaf $(r=0.8357, p=0.38)$; the number of ducts in the ground parenchyma of the midrib, which was positively correlated with the midrib width $(\mathrm{r}=0.6482, p=0.164)$ and the leaf area $(\mathrm{r}=0.5573$, $p=0.251)$; and the thickness of the mesophyll. The leaf area, which did not differ between the populations, was negatively correlated with the SI of the abaxial surface $(\mathrm{r}=-0.8699, p=0.24)$. Midrib width also was positively correlated with leaf area $(\mathrm{r}=0.8046, p=0.054)$, midrib height $(\mathrm{r}=0.7322, p=0.098)$, adaxial epidermis height $(\mathrm{r}=0.6118, p=0.197)$, and adaxial and abaxial outer periclinal external wall thickness $(\mathrm{r}=0.9034, p=0.014$ and $\mathrm{r}=0.6343, p=0.176$, respectively).

The stem features were more similar (Table 3), and no statistically significant difference was noted among the sites for any of the parameters evaluated. However, the internode diameter values, cortex thickness, stem area, and vascular cylinder area were lower for individuals from site 6 . Moreover, these parameters were strongly correlated, such as internode diameter and vascular cylinder area $(\mathrm{r}=0.9216, p=0.009)$, cortex thickness and stem internode area $(\mathrm{r}=0.46, p=0.8199)$, and total stem and vascular cylinder area $(\mathrm{r}=0.9199, p=0.01)$.

Secretory duct arrangements: The duct arrangements found in the ground parenchyma of the midrib were based on Filartiga et al. (2016) who described 23 different types of duct distributions. Different duct arrangements were found in A. grandiflora (Table 4), and the distribution in the different populations is shown in Table 5. The patterns varied within the same population and even within the same individual, depending on the section analyzed. Furthermore, two of the patterns found in A. grandiflora from populations 5 and 6 were not described before in any other Aldama species, even by Filartiga et al. (2016), who conducted a detailed study about secretory ducts in Brazilian Aldama species.

Soil analysis: For the micronutrients (Table 6), the largest variations were observed for the levels of copper, iron, and manganese for site 6 , which showed higher values than those for the other sites. The $\mathrm{pH}$ values of water and potassium chloride $(\mathrm{KCl})$, as well as phosphorus, calcium, manganese, and aluminum saturation ( $\mathrm{m}$ ) values, showed no variation among the six sites. The potassium content was slightly higher at site 6 . The aluminum content and potential acidity $(\mathrm{H}+\mathrm{Al})$ were higher at sites 5 and 6 than in the other localities. Site 5 also showed the highest values of cation exchange capacity (CEC), followed by that for site 6 . Regarding the CEC saturation by bases (V), site 5 showed the lowest values.
In relation to the soil particle size, site 6 showed the highest clay content and was classified as clayey soil. The soils from the other populations were classified as sandy medium (sites 1, 3, and 5) or clayey medium (sites 2, 4) soils.

Some of the anatomical parameters were correlated with the constituents evaluated for soil conditions. Among these parameters, the midrib height was positively correlated with iron content $(\mathrm{r}=0.8374, p=0.038)$, mesophyll thickness was negatively correlated with water $\mathrm{pH}(\mathrm{r}=-0.8178$, $p=0.047$ ) and positively correlated with aluminum content $(\mathrm{r}=0.8811, p=0.02)$, and cuticle thickness was negatively correlated with water $\mathrm{pH}(\mathrm{r}=-0.8677, p=0.025)$. Regarding stem parameters, a strong negative correlation was noted between the cortical thickness and levels of boron $(\mathrm{r}=-0.9069, p=0.013)$, copper $(\mathrm{r}=-0.9519, p=0.03)$, iron $(\mathrm{r}=-0.8149, p=0.048)$, manganese $(\mathrm{r}=-0.9431$, $p=0.005)$, and potassium $(\mathrm{r}=-0.8964 ; p=0.016)$, and a positive correlation was noted with the total amount of sand $(\mathrm{r}=0.9474, p=0.004)$. The total internode area and vascular cylinder area were also negatively correlated with iron content $(\mathrm{r}=-0.8740, p=0.023 ; \mathrm{r}=-0.8473$, $p=0.033)$ and clay amount in the soil $(\mathrm{r}=-0.9704$, $p=0.001 ; \mathrm{r}=-0.8863, p=0.019)$.

Environmental data: According to the data obtained from Worldclim (Table 7), Region 2 (sites 4, 5, and 6) had the highest mean annual temperature as well as the highest precipitation values. Elevation was higher in two of the three sites from Region 2. The mean annual temperature was positively correlated with the SI of leaf abaxial surface $(\mathrm{r}=0.8607, p=0.028)$ and, along with the annual precipitation, was positively correlated with the cuticle thickness $(\mathrm{r}=0.8305, p=0.41, \mathrm{r}=0.8880, p=0.018)$.

\section{Discussion}

We aimed to determine whether the different localities, and thus the different soil and climate conditions to which the six populations were exposed, were sufficient to modify the anatomical structure of the individuals. The leaf and stem parameters evaluated showed an anatomical constancy for the $A$. grandiflora individuals among the six sampled sites. For the leaf, seven of the thirteen parameters did not differ statistically among the sites; the stem features were even more consistent, and none differed statistically among the areas.

Among the parameters that showed statistical differences, the variations did not reflect the region from where the populations were sampled. The only parameter that differed between the two regions was cuticle thickness of the adaxial leaf surface, which was slightly thicker for individuals from Region 2. Cuticle plays an important role in reducing water loss, waterproofing, and sunlight reflection (Haberlandt, 1990; Larcher, 2000); its thickness and composition can be influenced by environmental factors (Esau, 1976; Dickison, 2000). In this study, thicker cuticles were correlated to places with higher mean temperature, which might have influenced this result. 

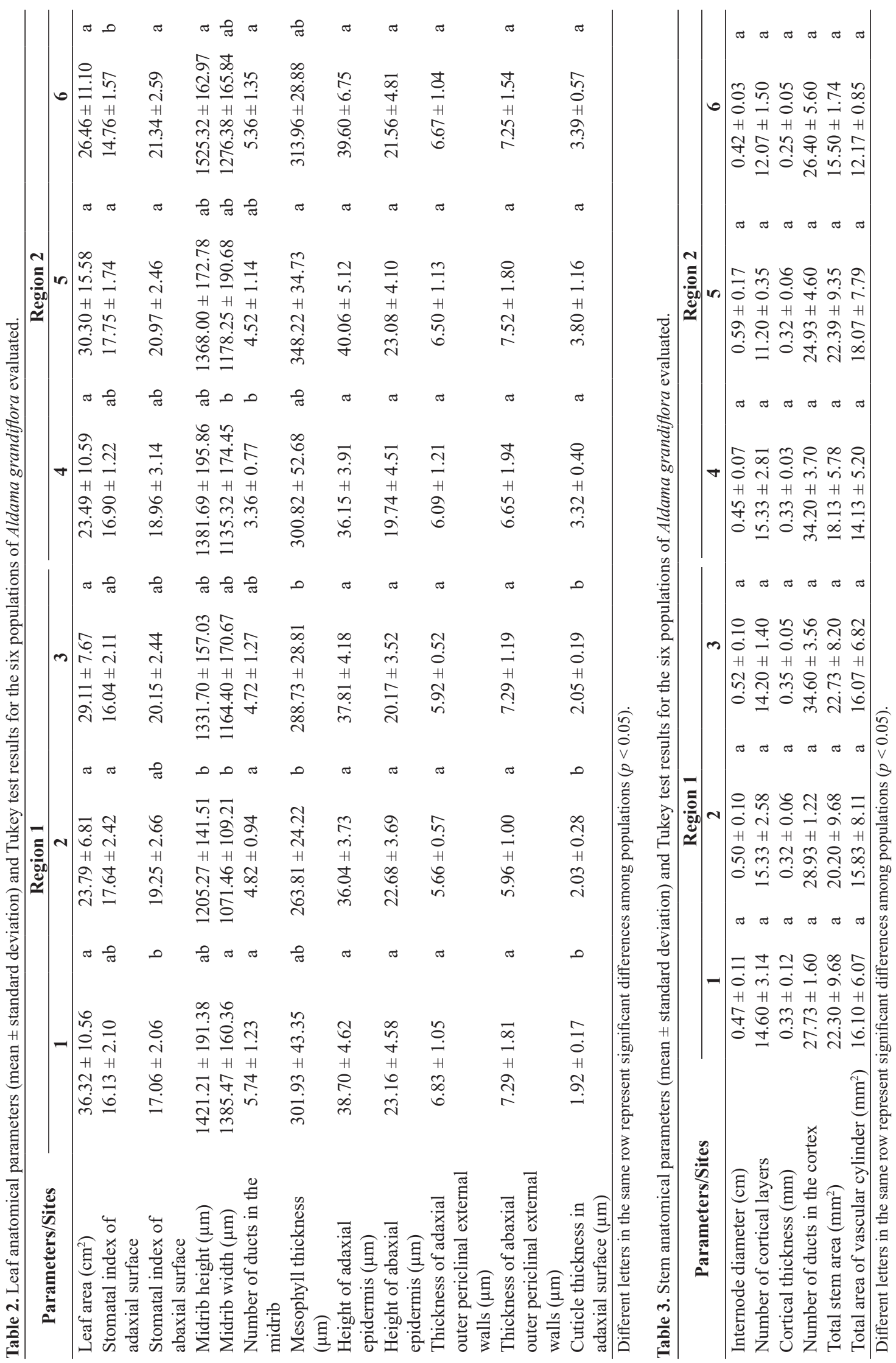
The morphometrical parameters evaluated in this study were not correlated to the altitude of the sites from where the populations were collected, likely because the difference between the amplitude of altitude among the sites was less pronounced than that of sites investigated by

Table 4. Secretory duct distribution patterns in the ground parenchyma of the midrib in Aldama grandiflora (Adapted from Filartiga et al., 2016).

Pattern Arrangement Pattern Arrangement

Table 5. Distribution patterns of secretory ducts in the ground parenchyma of the midrib of the six different populations of Aldama grandiflora, based on Filartiga et al. (2016).

\begin{tabular}{cc}
\hline Population & Distribution patterns \\
\hline 1 & IV; VIII; XIV; XV; XX \\
2 & XIV; XV; XVI; XIII; XVIII \\
3 & VIII; XIII; XIV; XV; XVI \\
4 & III; IV; VIII; IX; XIII \\
5 & III; XIII; XIV; XV; New 1 \\
6 & IV; V; XIV; XV; XVI; XIII; New 2 \\
\hline
\end{tabular}

Tiwari et al. (2013), who evaluated the anatomical differences in an altitude gradient of more than $1700 \mathrm{~m}$ and found that anatomical properties of needles in Pinus roxburghii Sarg. exhibited variation from lower to higher elevation.

The studied species, $A$. grandiflora, occurs exclusively in open areas of Cerrado (Magenta et al., 2010); it is subjected to typical Cerrado environmental conditions such as high solar radiation, low availability of nutrients in the soil like calcium and magnesium, and high aluminum levels, in addition to low water availability, mainly in the upper soil layers (Ratter et al., 1977). These conditions might influence the anatomy of plant species. The SI, which was one of the parameters that differed among the sites and showed a positive correlation with the annual mean temperature, showed the highest values for individuals from site 5, which were collected from a locality having one of the highest temperatures and altitude. High values of stomatal density and SI can be considered as an adaptation that can lead to an increase of the $\mathrm{CO}_{2}$ uptake (Dickison, 2000) and promote larger output of water vapor and internal cooling of leaves (Lima Junior et al., 2006), which is an important response to higher temperatures. High values of SI are also associated with higher elevations, and thus to a higher light incidence and lower content of available $\mathrm{O}_{2}$ and $\mathrm{CO}_{2}$ (Apel, 1989; Furukawa, 1997; Gardoni et al., 2007).

Taller epidermal cells with thicker walls can disperse more light, thereby protecting the photosynthetic tissues and avoiding leaf overheating and or protect photosynthetic tissues from excessive irradiance (Roth, 1984; Feller, 1996; Evert, 2006). Anticlinal or periclinal cell walls with more thickening are often found in species from regions subjected to water deficit (Solereder, 1908; Metcalfe and Chalk, 1979) and are related to the reduction of water loss by transpiration, decreasing heating within plant organs, maintaining its architecture, and reflecting higher luminosity (Dickison, 2000; Leite and Scatena, 2001). All the sampled individuals showed tall epidermal cells on the adaxial surface of the leaves as well as pectin-thickened external periclinal walls in both the leaf surfaces. Considering the studies of Marques et al. (2000), who reported that Miconia stenostachya showed an increase in thickness of cuticle and epidermis of leaves in the sun exposed cerrado and stated it may be related to an increase in leaf reflectance, we can suggest that taller epidermal cells with thicker walls are important characteristics for A. grandiflora to live in the open areas of Cerrado.

Leaves characters such as the type and position of secretory structures have been useful for species differentiation (Castro et al., 1997; Fahn, 2000; Oliveira et al., 2013), including in Asteraceae (Solereder, 1908; Metcalfe and Chalk, 1950; Wagenitz, 1976; Castro et al., 1997; Adedeji and Jewoola, 2008; Fritz and Saukel, 2011). However, some studies (Kakrani et al., 1991; Sheue et al., 2003; Filartiga et al., 2016) showed that the number and position of secretory ducts can vary, rendering it difficult to use this character as the only parameter of differentiation among species. As previously reported for other Brazilian Aldama species (Filartiga et al., 2016), in A. grandiflora, variation 
Table 6. Chemical and physical soil analysis for the six populations of Aldama grandiflora evaluated.

\begin{tabular}{|c|c|c|c|c|c|c|}
\hline \multirow{2}{*}{ Nutrients/Sites } & \multicolumn{3}{|c|}{ Region 1} & \multicolumn{3}{|c|}{ Region 2} \\
\hline & 1 & 2 & 3 & 4 & 5 & 6 \\
\hline$B\left(\mathrm{mg} \cdot \mathrm{dm}^{-3}\right)$ & $<0.12$ & $<0.12$ & $<0.12$ & $<0.12$ & 0.13 & 0.14 \\
\hline $\mathrm{Cu}\left(\mathrm{mg} \cdot \mathrm{dm}^{-3}\right)$ & $<0.3$ & $<0.3$ & $<0.3$ & $<0.3$ & $<0.3$ & 0.9 \\
\hline $\mathrm{Fe}\left(\mathrm{mg} \cdot \mathrm{dm}^{-3}\right)$ & 35 & 25 & 31 & 52 & 35 & 73 \\
\hline $\operatorname{Mn}\left(\mathbf{m g} \cdot \mathbf{d m}^{-3}\right)$ & 4.2 & 0.8 & 0.9 & 2.1 & 0.6 & 37.1 \\
\hline $\mathrm{Zn}\left(\mathbf{m g} \cdot \mathbf{d m}^{-3}\right)$ & $<0.4$ & $<0.4$ & $<0.4$ & $<0.4$ & $<0.4$ & $<0.4$ \\
\hline pH $\mathrm{H}_{2} \mathrm{O}$ & 5.3 & 5.4 & 5.3 & 5.2 & 5.2 & 5.2 \\
\hline pH KCl & 4 & 4.1 & 4.1 & 4 & 4.1 & 4 \\
\hline $\mathbf{P}\left(\mathbf{m g} \cdot \mathrm{kg}^{-1}\right)$ & 1 & 1 & 1 & $<1$ & 2 & 1 \\
\hline K (mmolc.kg-1) & 1.1 & 1.1 & 1 & 1.1 & 2 & 2.7 \\
\hline Ca (mmolc.kg-1) & $<2$ & $<2$ & 3 & $<2$ & $<2$ & $<2$ \\
\hline Mg (mmolc.kg-1) & $<1$ & $<1$ & 1 & 1 & 1 & 2 \\
\hline Al (mmolc.kg-1) & 15 & 15 & 14 & 17 & 41 & 24 \\
\hline $\mathbf{H}+\mathbf{A l}\left(\mathrm{mmolc} \mathrm{kg}^{-1}\right)$ & 31 & 52 & 27 & 34 & 151 & 77 \\
\hline SB (mmolc.kg-1) & 2.3 & 2.2 & 4.5 & 3 & 3.4 & 5.4 \\
\hline CEC (mmolc.kg-1) & 33.3 & 54.3 & 31.1 & 36.7 & 154 & 82.5 \\
\hline V $(\%)$ & 7 & 4 & 14 & 8 & 2 & 7 \\
\hline m (\%) & 87 & 87 & 75 & 85 & 92 & 82 \\
\hline Total sand (g.kg-1) & 709 & 611 & 772 & 630 & 485 & 268 \\
\hline Silt $\left(g^{\prime} \cdot \mathrm{kg}^{-1}\right)$ & 89 & 81 & 76 & 65 & 327 & 370 \\
\hline Clay (g.kg-1) & 202 & 208 & 151 & 305 & 188 & 362 \\
\hline Texture classes & $\begin{array}{l}\text { Sandy } \\
\text { medium }\end{array}$ & $\begin{array}{l}\text { Clayey } \\
\text { medium }\end{array}$ & $\begin{array}{c}\text { Sandy } \\
\text { medium }\end{array}$ & $\begin{array}{l}\text { Clayey } \\
\text { medium }\end{array}$ & $\begin{array}{l}\text { Sandy } \\
\text { medium }\end{array}$ & Clayey \\
\hline
\end{tabular}

SB: sum of exchangeable bases; CEC: cation exchange capacity; V: CEC base saturation; m: saturation of aluminum.

Table 7. Elevation $(\mathrm{m})$, annual temperature average $\left({ }^{\circ} \mathrm{C}\right)$, and annual precipitation $(\mathrm{mm})$ in the six localities evaluated.

\begin{tabular}{lccccccc}
\hline \multicolumn{1}{c}{$\begin{array}{l}\text { Parameter/ } \\
\text { Sites }\end{array}$} & \multicolumn{3}{c}{ Region 1 } & & \multicolumn{3}{c}{ Region 2 } \\
\cline { 2 - 4 } \cline { 6 - 8 } & $\mathbf{1}$ & $\mathbf{2}$ & $\mathbf{3}$ & $\mathbf{4}$ & $\mathbf{5}$ & $\mathbf{6}$ \\
\hline $\begin{array}{l}\text { Elevation } \\
\text { Mean annual } \\
\text { temperature }\end{array}$ & 1169 & 1079 & 1155 & & 1243 & 1206 & 1079 \\
$\begin{array}{l}\text { Annual } \\
\text { precipitation }\end{array}$ & 1593 & 1627 & 1429 & 1805 & 1839 & 1780 \\
\hline
\end{tabular}

Data obtained from Worldclim (Hijmans et al., 2005).

in the number and position of secretory ducts was found in the midrib ground parenchyma, and also was observed among individuals from different populations, individuals of the same population, and within the same individual.

In the species analyzed herein, the total number of secretory ducts found in the midrib parenchyma was correlated positively with the midrib width and the total leaf area, i.e., wider midribs indicate a greater number of secretory ducts. This correlation was not observed by Filartiga et al. (2016), who reported such a tendency only in the leaves of Aldama corumbensis, among the 17 species analyzed. However, the position of secretory ducts has been associated with the presence of vascular bundles (Gregio and Moscheta, 2006; Bombo et al., 2012) and, in the case of $A$. grandiflora, the midrib can present 3 to 5 collateral vascular bundles (Bombo et al., 2016), which certainly influences the midrib width and the number of secretory ducts in the ground parenchyma.

In relation to the duct distribution, Filartiga et al. (2016) identified 23 different patterns, based on the number and position of ducts in the ground parenchyma of the midrib. Of the 23 already reported distributions in Aldama species (Filartiga et al., 2016), 12 types, as well as two new patterns, were identified in A. grandiflora in this study. Thus, the results obtained in $A$. grandiflora for the number and distribution of secretory ducts in the midrib corroborate the results for the Aldama group, and reaffirm that considering only the number and position of secretory structures are not sufficient for the taxonomic delimitation of a species.

The nutrient requirement of herbaceous layers, which is an essential component in savanna vegetation, is extremely low, ensuring the high resilience of the Cerrado ecosystem, especially after disturbances such as fire (Batmanian and Haridasan, 1985; Villela and Haridasan, 1994). The sites investigated in this study, except site 4 , were exposed to recent fire incidences, confirmed by the base of the remaining carbonized branches (Figure $2 \mathrm{~F}$ ) and charcoal remains on the ground (Figure $2 \mathrm{~A}-\mathrm{C}, \mathrm{E}-\mathrm{F}$ ). In all these sites, A. grandiflora plants showed the highest sprouting ability after fire among all the other plants (field observation). Fire events in Cerrado, mainly in open areas where A. grandiflora usually occurs, control the dynamics of populations of shrubs and trees species (Hoffmann, 1998), and induce 
flowering and renewal of the herbaceous stratum (Simon and Pennington, 2012).

The soil conditions in the evaluated sites showed higher amounts of iron in the soils from Region 2, especially in sites 4 and 6. This micronutrient is essential because it promotes plant development and plays an important role in chlorophyll synthesis as well as in respiration process and $\mathrm{N}_{2}$ fixation (Alexandre et al., 2012). Some of the leaf parameters were slightly higher for the individuals sampled from these sites, such as mesophyll and midrib thickness, and this could be related to the soil iron availability in the soil.

In addition to the high amounts of iron in the sampled soils, the soil $\mathrm{pH}$, which can influence the availability and deficiency of nutrients as well as the toxicity of these nutrients to plant species (Haridasan, 2008), was acidic (between 5.2 and 5.4). This values are characteristic of soils from Cerrado sensu stricto and open physiognomies of Cerrado (Lopes and Cox, 1977; Furley and Ratter, 1988; Haridasan, 1992). Although iron is known to be toxic to many plants, its toxicity occurs only under soil conditions that are more acidic (Haridasan, 2008) and, for A. grandiflora, the conditions did not seem to be harsh, since it showed the highest sprouting ability in the evaluated sites after a disturbance.

Soil fertility was low at site 4, especially with regard to the nutrients phosphorous and potassium; this site also showed lower water retention capacity, which was associated with the high total sand content in the upper soil layer. The relatively smaller size of individuals in this population (field observation) as well as lower values of foliar area and internode diameter might be associated with these soil features.

Ecological adaptation can often be associated with an unfavorable mineral nutrition (Ratter et al., 1977; Dickison, 2000), and Gardoni et al. (2007) showed that phenotypic variation found in Marcetia taxifolia (A. St.-Hil.) DC. (Melastomataceae) was related to the edaphic or geological conditions, since the variations did not reflect the geographical and/or climatic conditions. For Aldama grandiflora, some of the leaf and stem parameters showed significant variation among the sites, and exhibited positive or negative correlation with soil features, such as, the midrib size and mesophyll thickness that were positive correlated with levels of iron and aluminum, respectively, and total area of vascular cylinder and stem were correlated with iron levels. Although literature shows that aluminum and iron toxicity at low $\mathrm{pH}$ can directly influence plant development (Lopes and Cox, 1977; Haridasan, 2008), leading to the development of scleromorphic characters in cerrado plants (Goodland, 1971), the levels of iron and aluminum in the soil did not harm the development of Aldama grandiflora plants. Furthermore, A. grandiflora showed an anatomical stem development very similar to other species of the group already described (Bombo et al., 2012, 2014; Oliveira et al., 2013; Silva et al., 2014; Bombo et al., 2016), indicating a consistency within the genus and that this species is well adapted to these soil conditions.
In this study, A. grandiflora showed considerably consistency in leaf and stem anatomical characteristics since only slight morphometric differences were found among the populations analyzed. The variations observed were mainly correlated to the soil parameters, and the climatic conditions evaluated in this study had little influence on the morpho-anatomical features. Further studies including Aldama grandiflora populations from further locations could provide a wider understanding about how anatomical features in this species, and related ones, respond to uttermost envirormental conditions.

\section{Acknowledgements}

We thank São Paulo Council for Research (FAPESP; Thematic Project Proc. No., 2010/51454-3) for providing financial support and for granting scholarships to the first (2012/01586-6) and second (2012/02476-0) authors and The National Council for Scientific and Technological Development (CNPq) for grants (303715/2014-6) and scholarship to the third author $(2013 / 1602 ; 2014 / 897)$.

\section{References}

ADEDEJI, O. and JEWOOLA, O.A., 2008. Importance of leaf epidermal characters in the Asteraceae family. Notulae Botanicae Horti Agrobotanici Cluj-Napoca, vol. 36, no. 2, pp. 7-16.

ALEXANDRE, J.R., OLIVEIRA, M.L.F., SANTOS, T.C., CANTON, G.C., CONCEIÇÃO, J.M., EUTRÓPIO, F.J., CRUZ, Z.M.A., DOBBSS, L.B. and RAMOS, A.C., 2012. Zinco e ferro: de micronutrientes a contaminantes do solo. Natureza Online, vol. 10 , pp. 23-28.

APEL, P., 1989. Influence of $\mathrm{CO}_{2}$ on stomatal numbers. Biologia Plantarum, vol. 31, no. 1, pp. 72-74. http://dx.doi.org/10.1007/ BF02890681.

BAAS, P., 1982. Systematic, phylogenetic, and ecological wood anatomy - history and perspectives. In: B.P.N. MARTINUS, ed. New perspectives in wood anatomy. Hague: Junk Publishing, pp. 23-58.

BATMANIAN, G.J. and HARIDASAN, M., 1985. Primary production and accumulation of nutrients by the ground layer community of Cerrado vegetation of central Brazil. Plant and Soil, vol. 88, no. 3, pp. 437-440. http://dx.doi.org/10.1007/BF02197500.

BOMBO, A.B., FILARTIGA, A.L.P. and APPEZZATODA-GLORIA, B., 2016. Solving taxonomic problems within the Aldama genus based on anatomical characters. Australian Journal of Botany, vol. 64, pp. 501-512. [Print] http://dx.doi. org/10.1071/BT16070.

BOMBO, A.B., OLIVEIRA, T.S., OLIVEIRA, A.S.S., REHDER, V.L.G. and APPEZZATO-DA-GLÓRIA, B., 2014. Anatomy and essential oil composition of the underground systems of three species of Aldama La Llave (Asteraceae). The Journal of the Torrey Botanical Society, vol. 141, no. 2, pp. 115-125. http:// dx.doi.org/10.3159/TORREY-D-12-00053.1.

BOMBO, A.B., OLIVEIRA, T.S., OLIVEIRA, A.S.S., REHDER, V.L.G., MAGENTA, M.A.G. and APPEZZATO-DA-GLÓRIA, B., 2012. Anatomy and essential oils from aerial organs in three species of Aldama (Asteraceae-Heliantheae) that have a difficult 
delimitation. Australian Journal of Botany, vol. 60, no. 7, pp. 632-642. http://dx.doi.org/10.1071/BT12160.

BUKATSCH, F., 1972. Bermerkungenzur Doppelfarbung Astrablau-Safranin. Mikrokosmos, vol. 61, pp. 1.

CANALES, M., HERNÁNDEZ, T., RODRÍGUEZ-MONROY, M.A., JIMÉNEZ-ESTRADA, M., FLORES, C.M., HERNÁNDEZ, L.B., GIJÓN, I.C., QUIROZ, S., GARCÍA, A.M. and ÁVILA, G., 2008. Antimicrobial activity of the extracts and essential oil of Viguiera dentata. Pharmaceutical Biology, vol. 46, no. 10-11, pp. 719-723. http://dx.doi.org/10.1080/13880200802215727.

CARLQUIST, S., 1988. Comparative wood anatomy. Berlin: Springer-Verlag.

CASTRO, M.M., LEITÃO-FILHO, H.F. and MONTEIRO, W.R., 1997. Utilização de estruturas secretoras na identificação dos gêneros de Asteraceae de uma vegetação de cerrado. Brazilian Journal of Botany, vol. 20, no. 2, pp. 163-174. http://dx.doi. org/10.1590/S0100-84041997000200007.

CUTTER, E.G., 1986. Anatomia vegetal: parte I - células e tecidos. 2nd ed. São Paulo: Roca.

DICKISON, W.C., 2000. Integrative Plant Anatomy. San Diego: Elsevier.

ESAU, K., 1976. Anatomia das plantas com sementes. São Paulo: Edgard Blücher.

EVERT, R.F., 2006. Esau's plant anatomy: Meristems, cells, and tissue of the plant body: Their structure, function and development. 3rd ed. New Jersey: Wiley.

FAHN, A., 1986. Structural and functional properties of trichomes of xeromorphic leaves. Annals of Botany, vol. 57, no. 5, pp. 631-637. http://dx.doi.org/10.1093/oxfordjournals.aob.a087146.

FAHN, A., 2000. Structure and function of secretory cells. Advances in Botanical Research, vol. 31, pp. 37-75. http://dx.doi. org/10.1016/S0065-2296(00)31006-0.

FELLER, I.C., 1996. Effects of nutrient enrichment on leaf anatomy of dwarf Rhizophora mangle L. (red mangrove). Biotropica, vol. 28, no. 1, pp. 13-22. http://dx.doi.org/10.2307/2388767.

FILARTIGA, A.L., BASSINELLO, V., FILIPPI, G.M., BOMBO, A.B. and APPEZZATO-DA-GLÓRIA, B., 2016. Secretory duct distribution and leaf venation patterns of Aldama species (Asteraceae) and their application in taxonomy. Botany, vol. 94, no. 12, pp. 1161-1170. http://dx.doi.org/10.1139/cjb-2016-0172.

FRITZ, E. and SAUKEL, J., 2011. Secretory structures of subterranean organs of some species of the Cardueae and their diagnostic value. Acta Biologica Cracoviensia, vol. 53, no. 1, pp. 63-73.

FURLEY, P.A. and RATTER, J.A., 1988. Soil resources and plant communities of the Central Brazilian cerrado and their development. Journal of Biogeography, vol. 15, no. 1, pp. 97108. http://dx.doi.org/10.2307/2845050.

FURUKAWA, A., 1997. Stomatal frequency of Quercus myrsinaefolia grown under different irradiances. Photosynthetica, vol. 34, no. 2, pp. 195-199. http://dx.doi.org/10.1023/A:1006884306017.

GARDONI, L.C.P., ISAIAS, R.M.S. and VALE, F.H.A., 2007. Morfologia e anatomia foliar de três morfotipos de Marcetia taxifolia (A. St.-Hil.) DC. (Melastomataceae) na Serra do Cipó, MG. Revista Brasileira de Botânica, vol. 30, no. 3, pp. 487-500.
GOODLAND, R. 1971. Oligotrofismo e alumínio no cerrado. In: M.G. Ferri, ed. Anais do III Simpósio sobre o Cerrado, 1971, São Paulo. São Paulo: EDUSP, pp. 44-60.

GREGIO, S.J.D. and MOSCHETA, I.S., 2006. Anatomia de raiz, caule e folha e identificação de estruturas secretoras de Achillea millefolium L. (Alteraceae). Acta Scientiarum. Biological Sciences, vol. 28 , no. 4 , pp. 327-334.

HABERLANDT, G., 1990. Physiological plant anatomy. 2nd ed. New Delhi: Today \& Tomorrow's Printers \& Publishers.

HARIDASAN, M. 1992. Observations on soils, foliar nutrient concentrations and floristic composition of cerrado and cerradão communities in central Brazil. In: J. Proctor, J.A. Ratter and P.A. Furley, eds. The Nature and Dynamics of forest-savanna boundaries. Londres: Chapman e Hall pp. 171-184.

HARIDASAN, M., 2008. Nutritional adaptations of native plants of the Cerrado biome in acid soils. Brazilian Journal of Plant Physiology, vol. 20, no. 3, pp. 183-195. http://dx.doi.org/10.1590/ S1677-04202008000300003.

HOFFMANN, W.A., 1998. Post-burn reproduction of woody plants in a neotropical savanna: the relative importance of sexual and vegetative reproduction. Journal of Applied Ecology, vol. 35, no. 3, pp. 422-433. http://dx.doi.org/10.1046/j.1365-2664.1998.00321.x.

HIJMANS, R.J., CAMERON, S.E., PARRA, J.L., JONES, P.G., JARVIS, A., 2005 [viewed 28 September 2015]. Very high resolution interpolated climate surfaces for global land areas. International Journal of Climatology, vol. 25, pp. 1965-1978. Available from: http://www.worldclim.org/

JENSEN, W., 1962. Botanical histochemistry, principles, and practice. San Francisco: W. H. Freeman.

JOHANSEN, D., 1940. Plant microtechnique. New York: McGraw-Hill Book Co. Inc.

KAKRANI, H.K., KALYANI, G.A., BALAIDAVAR, G.P., SATYANARAYANA, D. and MANVI, F.V., 1991. Pharmacognostical studies on the leaves of Commiphora mukul Hook ex Stocks. Ancient Science of Life, vol. 10, no. 3, pp. 165171. PMid:22556527.

KOLMOGOROV, A.N., 1933. Sulla determinazione empirica di una legge di distribuzione. Giornale dell Istituto degli Attuari, vol. 4, pp. 83-91.

KUNIYOSHI, Y.S., 1993. Aspectos morfo-anatômicos do caule, raiz e folha de Tabebuia cassinoides (Lam.) DC. (Bignoniaceae) em diferentes fases sucessionais no litoral do Paraná. Curitiba: Universidade Federal do Paraná. Tese de Doutorado.

LARCHER, W., 2000. Ecofisiologia vegetal. São Carlos: Rima.

LEITE, A.M., LIMA, E.O., SOUZA, E.L., DINIZ, M.F.F.M., TRAJANO, V.N. and MEDEIROS, I.A., 2007. Inhibitory effect of $\beta$-pinene, $\alpha$-pinene and eugenol on the growth of potential infectious endocarditis causing gram-positive bacteria. Brazilian Journal of Pharmaceutical Sciences, vol. 43, pp. 121-126.

LEITE, K.R.B. and SCATENA, V.L., 2001. Anatomia do segmento foliar de espécies de Syagrus Mart. (Arecaceae) da Chapada Diamatina, Bahia, Brasil. Sitientibus Série Ciências Biológicas, vol. 1, pp. 3-14.

LILLIEFORS, H.W., 1967. On the Kolmogorov-Smirnov test for normality. Biometrika, vol. 62, no. 3, pp. 399-402.

LIMA JUNIOR, E.C., ALVARENGA, A.A., CASTRO, V.V. and BARBOSA, J.P.R.A., 2006. Aspectos fisioanatômicos de 
plantas jovens de Cupania vernalis Camb. submetidas a diferentes níveis de sombreamento. Revista Árvore, vol. 30, no. 1, pp. 33-41.

LOPES, A.J. and COX, F.R., 1977. A survey of the fertility status of surface soils under Cerrado vegetation of Brazil. Soil Science Society of America Journal, vol. 41, no. 4, pp. 752-757. http://dx.doi.org/10.2136/sssaj1977.03615995004100040026x.

MAGENTA, M.A.G. and PIRANI, J.R., 2014. Novidades taxonômicas em Aldama (Asteraceae-Heliantheae). Rodriguésia, vol. 65 , no. 1, pp. 175-192. http://dx.doi.org/10.1590/S217578602014000100012 .

MAGENTA, M.A.G., 2006. Viguiera Kunth (Asteraceae, Heliantheae) na América do Sul e sistemática das espécies do Brasil. São Paulo: Universidade de São Paulo.

MAGENTA, M.A.G., PIRANI, J.R. and MONDIN, C.A., 2010. Novos táxons e combinações em Viguiera (AsteraceaeHeliantheae). Rodriguésia, vol. 61, no. 1, pp. 1-11. http://dx.doi. org/10.1590/2175-7860201061101.

MARQUES, A.R., GARCIA, Q.S., REZENDE, J.L.P. and FERNANDES, G.W., 2000. Variations in leaf characteristics of two species of Miconia in the Brazilian cerrado under different light intensities. Tropical Ecology, vol. 41, no. 1, pp. 47-60.

METCALFE, C.R. and CHALK, L., 1950. Anatomy of the Dicotyledons: leaves, stem and wood in relation to taxonomy with notes on economic uses. Oxford: Clarendon Press.

METCALFE, C.R. and CHALK, L., 1979. Anatomy of the dicotyledons, systematic anatomy of the leaf and stem. vol. 1. Oxford: Clarendon Press.

METCALFE, C.R. and CHALK, L., 1983. Anatomy of the dicotyledons. 2nd ed. vol. 2. Oxford: Clarendon Press.

OLIVEIRA, T.S., BOMBO, A.B. and APPEZZATO-DAGLÓRIA, B., 2013. Anatomy of vegetative organs with an emphasis on the secretory structures of two species of Aldama (Asteraceae-Heliantheae). Botany, vol. 91, no. 3, pp. 335-342. http://dx.doi.org/10.1139/cjb-2012-0271.

OLSEN, J.T., CAUDLE, K.L., JOHNSON, L.C., BAER, S.G. and MARICLE, B.R., 2013. Environmental and genetic variation in leaf anatomy among populations of Andropogon gerardii (Poaceae) along a precipitation gradient. American Journal of Botany, vol. 100, no. 10, pp. 1957-1968. PMid:24061213. http:// dx.doi.org/10.3732/ajb.1200628.

PANERO, J.L. and CROZIER, B.S., 2012 [viewed 28 April 2016]. Asteraceae. Sunflower, daisies. Version 27- the tree of life web project [online]. Available from: http://tolweb.org/

RASBAND, W.S., 2006 [viewed 30 August 2016]. Image J [online]. Maryland: Bethesda, United States Nacional Institute of Health. Available from: https://imagej.nih.gov/ij/index.html

RATTER, J.A., ASKEW, G.D., MONTGOMERY, R.F. and GIFFORD, D.R., 1977. Observações adicionais sobre o cerradão de solos mesotróficos no Brasil Central. In: M.G. FERRI, ed. Anais do IV Simpósio Sobre o Cerrado, 1977, São Paulo. São Paulo: EDUSP, pp. 306-316.

ROTH, J., 1984. Stratification of tropical forests as seen in leaf structure. The Hague: W. Junk.

SAKAI, W.S., 1973. Simple method for differential staining of paraffin-embedded plant material using toluidine blue O. Stain
Technology, vol. 48, no. 5, pp. 247-249. PMid:4126691. http:// dx.doi.org/10.3109/10520297309116632.

SANTOS, M.R.V., MOREIRA, F.V., FRAGA, B.P., SOUZA, D.P., BONJARDIM, L.R. and QUINTANS-JUNIOR, L.J., 2011. Cardiovascular effects of monoterpenes: a review. Brazilian Journal of Pharmacognosy, vol. 21, pp. 764-771.

SCHEINER, S.M., 1993. Genetics and evolution of phenotypic plasticity. Annual Review of Ecology Evolution and Systematics, vol. 24, no. 1, pp. 35-68. http://dx.doi.org/10.1146/annurev. es.24.110193.000343.

SCHILLING, E. and PANERO, J., 2011. A revised classification of subtribe Helianthinae (Asteraceae: Heliantheae) II. Derived lineages. Botanical Journal of the Linnean Society, vol. 167, no. 3, pp. 311-331. http://dx.doi.org/10.1111/j.1095-8339.2011.01172.x.

SHAPIRO, S.S. and WILK, M.B., 1965. An analysis of variance test for normality (complete sample). Biometrika, Great Britain, vol. 52, no. 3, pp. 591-611. http://dx.doi.org/10.1093/biomet/52.3-4.591.

SHEUE, C.R., YANG, Y. and KUO-HUANG, L., 2003. Altitudinal variation of resin ducts in Pinus taiwanensis Hayata (Pinaceae) needles. Botanical Bulletin of Academia Sinica, vol. 44, no. 4, pp. 305-313.

SILVA, E.M.S., HAYASHI, A.H. and APPEZZATO-DAGLÓRIA, B., 2014. Anatomy of vegetative organs in Aldama tenuifolia and A. kunthiana (Asteraceae: Heliantheae). Brazilian Journal of Botany, vol. 37, no. 4, pp. 505-517. http://dx.doi. org/10.1007/s40415-014-0101-2.

SIMON, M.F. and PENNINGTON, T., 2012. Evidence for adaptation to fire regimes in the tropical savannas of the Brazilian Cerrado. International Journal of Plant Sciences, vol. 173, no. 6, pp. 711-723. http://dx.doi.org/10.1086/665973.

SOLEREDER, H., 1908. Systematic anatomy of the dicotyledons: a handbook for laboratories of pure and applied botany. Oxford: Clarendon Press.

STEARNS, S.C., 1989. The evolutionary significance of phenotypic plasticity. Bioscience, vol. 39, no. 7, pp. 436-445. http://dx.doi. org/10.2307/1311135.

STEVENS, P.F., 2001 [viewed 28 April 2016]. Angiosperm Phylogeny website. v. 8 [online]. Available from: http://www. mobot.org/MOBOT/research/APweb/

TIWARI, S.P., KUMAR, P., YADAV, D. and CHAUHAN, D.K., 2013. Comparative morphological, epidermal, and anatomical studies of Pinus roxburghii needles at different altitudes in the North-West Indian Himalayas. Turkish Journal of Botany, vol. 37 , pp. 65-73.

VILLELA, D.M.V. and HARIDASAN, M., 1994. Response of the ground layer community of a Cerrado vegetation in central Brazil to liming and irrigations. Plant and Soil, vol. 163, no. 1, pp. 25-31. http://dx.doi.org/10.1007/BF00033937.

WAGENITZ, G., 1976. Systematics and phylogeny of the Compositae (Asteraceae). Plant Systematics and Evolution, vol. 25, no. 1, pp. 29-46. http://dx.doi.org/10.1007/BF00986129.

YALTIRIK, F., 1970. Comparison of anatomical characteristics of wood in Turkish maples with relation to the humidity of the sites. Journal of the Institute of Wood Science, vol. 25, no. 5, pp. 43-48. 